\title{
HYPOMETHYLATION OF DEOXYRIBONUCLEIC ACID IN TESTICULAR TISSUE DUE TO ARSENIC EXPOSURE IN MICE
}

\author{
AKHILESHWARI NATH ${ }^{1}$, PRIYANKA ${ }^{1 *}$, ASEEM KUMAR ANSHU ${ }^{1}$, CHANDAN KUMAR SINGH $^{1}$, \\ SACHIDANANDA BEHERA ${ }^{1}$, JITENDRA KUMAR SINGH ${ }^{2}$
}

\author{
${ }^{1}$ Research Institute, S. S. Hospital and Research Institute, Patna, Bihar, India. ${ }^{2}$ Department of Oncology, S. S. Hospital and Research \\ Institute, Patna, Bihar, India. Email: priyankapgbt@gmail.com
}

Received: 28 August 2016, Revised and Accepted: 14 September 2016

\section{ABSTRACT}

Objective: Among various environmental carcinogens, arsenic is highly sensitive and possesses potential to cause several diseases including cancer Nevertheless, arsenic has not been observed to induce mutation directly but is involved in epigenetic changes. Hypomethylation of oncogenes and hypermethylation of tumor suppressor genes are reported to be associated with accumulation of arsenic. The present investigation demonstrates a direct correlation arsenic and deoxyribonucleic acid (DNA) methylation.

Methods: Swiss albino mice were grouped as control and arsenic treated for 12 weeks. Arsenic concentration in blood and testes was analyzed by atomic absorption spectrometer. Furthermore, DNA was extracted from the testes of mice by DNA purification kit and used for determining global methylation in mice genome with the help of MethylFlash Methylated DNA Quantification Kit.

Results: Arsenic concentration in arsenic-treated mice was significantly higher than the control group in both blood and testes. Interestingly, arsenic concentration in blood was recorded to be higher than testes in the arsenic-treated group with significance $(\mathrm{p}<0.0001)$. Moreover, a lower percentage of cytosine of mice genome was found to be methylated in arsenic-treated mice group than control group $(\mathrm{p}<0.0001)$.

Conclusion: Greater concentration of arsenic in mice leads to hypomethylation of mice genome globally. Arsenic fosters deregulation of gene expression by modifying methylation of CpG island of the promoter region. Epigenetic study is of prime importance in the field of oncology. Drug development for repressing alteration of DNA methylation is imperative for cancer treatment.

Keywords: Arsenic, Cancer, Deoxyribonucleic acid, Methylation, Carcinogen.

(C) 2016 The Authors. Published by Innovare Academic Sciences Pvt Ltd. This is an open access article under the CC BY license (http://creativecommons. org/licenses/by/4. 0/) DOI: http://dx.doi.org/10.22159/ajpcr.2016.v9s3.14932

\section{INTRODUCTION}

Arsenic, a metalloid released from both natural and anthropogenic sources, is a major health concern in many countries and has been associated with many human cancers [1,2]. In addition, chronic exposure of arsenic is also usually linked with many other diseases including abnormalities related to the reproductive system [3]. Metals such as arsenic may affect male reproductive system directly when it targets specific reproductive organ or indirectly when it targets neuroendocrine system. The deleterious effect of arsenic on spermatogenesis can be long lasting and irreversible if the Sertoli cells are damaged. The number of motile sperm produced during adulthood is determined by the number of Sertoli cells because each Sertoli cell supports the maturation of an only limited number of germ cells to sperm. Inorganic arsenic is an endocrine disruptor which is demonstrated to jeopardize the process of spermatogenesis leading to lower sperm count, impair the stability sperm chromatin or sperm deoxyribonucleic acid (DNA) damage [4].

Inorganic arsenic is primarily metabolized in the liver and converted to the organic entity. Thereafter, the organic arsenic is distributed to the entire body by peripheral blood. The excretion of arsenic has been observed to be miniature. According to a study, the highest amount of arsenic excreted was in form of monomethylarsonic acid (MMA) followed by dimethylarsinic acid (DMA) and inorganic arsenic [5]. An autoradiographic study of 74As-arsenite (As III) injected intravenously in mice showed the highest accumulation of arsenic in skeleton and long-term retention in hair and skin, squamous epithelium of gastrointestinal tract, the epididymis, thyroid, and lens [6]. In another study, $80 \%$ of the oral dosed arsenic was observed in gastrointestinal tract and the highest initial retention was found in kidney, lungs, intestinal mucosa, stomach, and testes [7]

Both genetic alteration (mutation) and epigenetic changes (methylation) have been linked with environmental carcinogenesis. Chronic exposure of low dose of arsenic to the non-tumorigenic prostate epithelial cells transformed to tumorigenic cells [8]. Several mechanisms at molecular and cellular levels have been proposed to explain the carcinogenicity induced by arsenic. Global DNA hypomethylation and activation of various oncogenes have been reported in the literature [8,9]. If the arsenic, by any mean, is ingested by humans, the inorganic arsenic is converted to organic forms, i.e., MMA and DMA in liver [10]. Since methylation of inorganic arsenic is considered to be detoxification process evolved by our body because methylated arsenic has lower toxic effect as compared to that of inorganic arsenic $[11,12]$. The conversion of inorganic arsenic to DMA or MMA is catalyzed by an enzyme called methyltransferase. Methyltransferase is an indigenous enzyme which transfers methyl group from s-adenosylmethionine to cytosine of $\mathrm{CpG}$ island of the promoter region. However, in this context, methyltransferase transfers methyl group from inorganic arsenic to $\mathrm{CpG}$ island and vice versa leading to hypermethylation or hypomethylation of $\mathrm{CpG}$ island of various oncogenes and tumor suppressor genes. Hypermethylation and hypomethylation were linked to tumor suppressor gene inactivation and oncogene activation, respectively [13-15].

This study aims to investigate the effect of acute toxicity by arsenic on gene expression and attempts to establish a correlation between accumulation of arsenic in the body and its ability to modify the methylation pattern. Arsenic, a potent carcinogen, has been shown to possess the capability to alter gene expression at epigenetic level in this study. 


\section{METHODS}

\section{Animals}

Swiss albino mice (Mus musculus) were reared in the animal house of S.S. Hospital and Research Institute, Patna. The male mice selected for the study were 12 weeks old, and their weight was measured as $30 \pm 2 \mathrm{~g}$. The mice were kept in the polypropylene cages with paddy husk at room temperature $28 \pm 2^{\circ} \mathrm{C}$ and humidity $50 \pm 5 \%$ in a controlled light $(12 \mathrm{hrs}$ light and $12 \mathrm{hrs}$ dark). Animals were maintained in ideal conditions as per the ethical guidelines of the CPCSEA (CPCSEA Regd. No. 1840/PO/ $\mathrm{ReBi} / \mathrm{S} / 5 / \mathrm{CPCSEA}$ ), Government of India, and Institutional Animal Ethics Committee (IAEC).

\section{Study groups and sampling}

Male mice of the control group $(n=6)$ were given distilled water as drinking water, and "treated group" ( $\mathrm{n}=6)$ were administered $2 \mathrm{mg} / \mathrm{kg}$ body weight of endosulfan for 12 weeks. Blood samples were collected from the sacrificed mice and centrifuged to obtain serum samples for estimation of arsenic concentration. Testes from all the animals were removed and stored at $-80^{\circ} \mathrm{C}$ for estimation of arsenic concentration and DNA methylation.

\section{Atomic absorption spectrometer}

Tissues of 6 controls and 6 arsenic-treated male mice stored at $-80^{\circ} \mathrm{C}$ for estimation of arsenic concentration. Further, sample preparation and estimation of arsenic was done by standard protocol of atomic absorption spectrometer graphite flame (Perkin Elmer) model number AAN3160080 (PinnAAcle900T)

\section{DNA isolation}

The testes tissue of male mice was homogenized in liquid nitrogen with the help of mortar and pestle. DNA from the testes was extracted by standard protocol of DNA purification kit (Promega, Wizard Genomic DNA Purification Kit, A1120).

\section{DNA methylation}

The isolated DNA was stored at $2-4^{\circ} \mathrm{C}$ overnight and processed for DNA methylation next day. The DNA methylation was assessed with the help of MethylFlash Methylated DNA Quantification Kit (EPIGENTEK).

\section{Statistical analysis}

T-test was performed to generate significance of DNA methylation and two-way ANOVA for arsenic concentration in blood and testes. $p<0.05$ was considered significance. Statistical analysis was performed with the help of SPSS 16.

\section{RESULTS AND DISCUSSION}

Blood and testes collected after dissection of the mice were used for estimation of arsenic concentration. The mean arsenic concentration in blood of arsenic-treated mice $(316.36 \pm 43.607 \mathrm{ppb})$ was recorded to be higher than the mean arsenic concentration in blood of control group $(1.005 \pm 0.885522 \mathrm{ppb})$. Similarly, the mean value of arsenic concentration in testes of arsenic-treated mice $(128.3 \pm 31.423 \mathrm{ppb})$ was observed to be higher than that of arsenic concentration in testes of the control group $(0.7 \pm 1.274 \mathrm{ppb})$ as shown in Fig. 1. Importantly, arsenic concentration in blood was significantly greater than in testes of arsenic-treated group and both higher than the control with significance value $\left({ }^{*} \mathrm{p}<0.0001\right)$.

The isolated DNA from testes from each group was tested for the global methylation of active genes in the genome of mice. $0.457 \%$ of the mice genome was found to be methylated in the control group, and only $0.21 \%$ of genome was methylated in arsenic-treated mice group with significance value $\left({ }^{* *} \mathrm{p}<0.0001\right)$ as shown in Fig. 2.

Ambiguous nature of arsenic, a deadly poison, a carcinogen, and antitumor capacity [16] makes it more interesting and hence rivets us to explore more to understand the elaborate mechanism by which it causes toxicity. Most satisfying mechanisms proposed for its carcinogenicity were by inducing double strand break leading to chromosomal aberration [17] and its capacity to induce changes in DNA methylation [9]. We have demonstrated how arsenic affects methylation of DNA on global genome.

Accumulation of arsenic in different organs in mice and humans is evident and has been reported several times in literature $[5,6]$. Exposure to arsenic has been observed to cause prostate cancer in humans and liver cancer in mice $[18,19]$. Mutation caused by arsenic has not been evident till date but epigenetic changes by altering methylation of promoter of genes are superfluous in the literature [20-22]. Arsenic has also been shown to cause hypermethylation of tumor suppressor genes [18]. According to a recent report, hypomethylation of DNA was observed in the genome of mice exposed to low dose of arsenic for shorter period, and hypermethylation was recorded in mice with chronic exposure of arsenic [23].

In the current investigation, mice were exposed to arsenic contaminated water of 200,000 ppb daily for 3 months. The concentration of arsenic in testes of mice after 3 months was observed 128 ppb (Fig. 1). The accumulation of arsenic is in testes is high enough to cause epigenetic changes. $<1 \%$ of genome contains exones in mammals that code for proteins and our data show only $0.21 \%$ cytosine methylation in arsenictreated mice as compared to $0.457 \%$ in control (Fig. 2). To convert inorganic arsenic to organic one, methyltransferase transfers the excess methyl group from $\mathrm{CpG}$ island of promoter to pentavalent or tetravalent arsenic. If arsenic is accumulated in higher concentration, the promoter region would so become hypomethylated as a consequence leading to altered gene expression which might include several oncogenes.

\section{CONCLUSION}

In the field of epigenetic study, arsenic is a potent toxic agent and carcinogen which leads to hypomethylation of oncogenes and

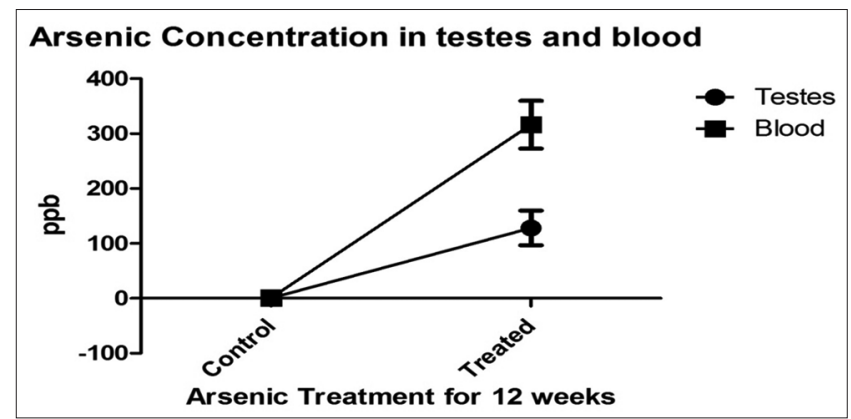

Fig. 1: Arsenic concentration in blood and testes of arsenictreated mice and control with mean \pm standard deviation $(* \mathbf{p}<0.0001)$

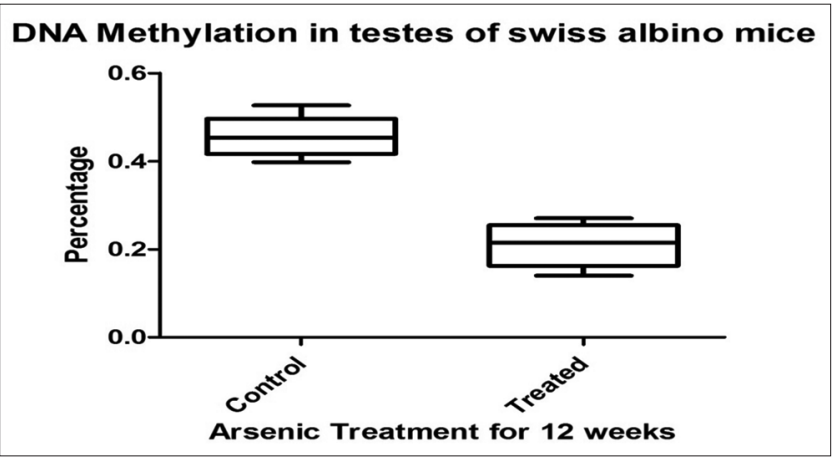

Fig. 2: Mean \pm standard deviation of percentage of global methylation in genome extracted from testes of control and arsenic-treated mice group $(* * p<0.0001)$ 
hypermethylation of tumor supressor genes. Acute exposure of arsenic for 3 months leads to global hypomethylation of DNA in mice. Since arsenic is accumulated in high concentration in testes, the genome becomes vulnerable to epigenetic changes. Apart from direct or indirect mutation in oncogene or tumor suppressor genes, epigenetic modification due to toxicity has emerged as a new and yet challenging mechanism of carcinogenesis which needs to be studied extensively.

\section{ACKNOWLEDGMENT}

Authors are thankful to ICMR, New Delhi, for financial support to the study and to S. S. Hospital and Research Institute, for providing infrastructure facilities. We are also indebted to Dr. A.K. Saxena, Head Department of Pathology and Laboratory Medicine, AIIMS, Patna, for his kind cooperation. We are also thankful to Mahavir Cancer Institute and Research Centre, Patna, for technical support.

\section{REFERENCES}

1. IARC. Some Drinking-Water Disinfectants and Contaminants, Including Arsenic. Vol. 84. Geneva, Switzerland: WHO Press; 2004 Available from: http://www.monographs.iarc.fr/ENG/Monographs/ vol84/index.php.

2. ATSDR. Toxicological Profile for Arsenic. GA, USA; Department of Health and Human Services, Public Health Service; 2007. Available from: http://www.atsdr.cdc.gov/toxprofiles/tp2.html

3. Kesari VP, Kumar A, Khan PK. Induction of sperm impairments in mice as a sensitive biomarker of arsenic toxicity. Environ Monit Assess 2014;186(5):3115-21

4. Chandra KA, Sengupta P, Goswami H, Sarkar M. Excessive dietary calcium in the disruption of structural and functional status of adult male reproductive system in rat with possible mechanism. Mol Cell Biochem 2012;364(1-2):181-91.

5. Buchet JP, Lauwerys R, Roels H. Comparison of the urinary excretion of arsenic metabolites after a single oral dose of sodium arsenite, monomethylarsonate, or dimethylarsinate in man. Int Arch Occup Environ Health 1981;48(1):71-9.

6. Lindgren A, Vahter M, Dencker L. Autoradiographic studies on the distribution of arsenic in mice and hamsters administered 74As-arsenite or - Arsenate. Acta Pharmacol Toxicol (Copenh) 1982;51(3):253-65.

7. Vahter M, Marafante E, Dencker L. Tissue distribution and retention of 74As-dimethylarsinic acid in mice and rats. Arch Environ Contam Toxicol 1984;13(3):259-64

8. Benbrahim-Tallaa L, Waterland RA, Styblo M, Achanzar WE, Webber MM, Waalkes MP. Molecular events associated with arsenicinduced malignant transformation of human prostatic epithelial cells Aberrant genomic DNA methylation and K-ras oncogene activation. Toxicol Appl Pharmacol 2005;206(3):288-98

9. Zhao CQ, Young MR, Diwan BA, Coogan TP, Waalkes MP.
Association of arsenic-induced malignant transformation with DNA hypomethylation and aberrant gene expression. Proc Natl Acad Sci U S A 1997;94(20):10907-12.

10. Stýblo M, Drobná Z, Jaspers I, Lin S, Thomas DJ. The role of biomethylation in toxicity and carcinogenicity of arsenic: A research update. Environ Health Perspect 2002;110 Suppl 5:767-71.

11. Yamauchi H, Fowler BA. Toxicity and metabolism of inorganic and methylated arsenicals. In: Nriagu JO, editor. Arsenic in the Environment, Part II: Human Health and Ecosystem Effects. New York: Wiley; 1994. p. 35-43.

12. Hirano S, Cui X, Li S, Kanno S, Kobayashi Y, Hayakawa T, et al. Difference in uptake and toxicity of trivalent and pentavalent inorganic arsenic in rat heart microvessel endothelial cells. Arch Toxico 2003;77(6):305-12.

13. Esteller M. CpG island hypermethylation and tumor suppressor genes A booming present, a brighter future. Oncogene 2002;21(35):5427-40

14. Diala ES, Hoffman RM. Hypomethylation of HeLa cell DNA and the absence of 5-methylcytosine in SV40 and adenovirus (Type 2) DNA Analysis by HPLC. Biochem Biophys Res Commun 1982;107(1):19-26.

15. Feinberg AP, Vogelstein B. Hypomethylation distinguishes genes of some human cancers from their normal counterparts. Nature 1983;301(5895):89-92

16. Bode AM, Dong Z. The paradox of arsenic: Molecular mechanisms of cell transformation and chemotherapeutic effects. Crit Rev Oncol Hematol 2002;42(1):5-24.

17. Okayasu R, Takahashi S, Sato H, Kubota Y, Scolavino S, Bedford JS Induction of DNA double strand breaks by arsenite: Comparative studies with DNA breaks induced by X-rays. DNA Repair (Amst) 2003;2(3):309-14.

18. Marsit CJ, Karagas MR, Danaee H, Liu M, Andrew A, Schned A, et al. Carcinogen exposure and gene promoter hypermethylation in bladder cancer. Carcinogenesis 2006;27(1):112-6.

19. Chen H, Li S, Liu J, Diwan BA, Barrett JC, Waalkes MP. Chronic inorganic arsenic exposure induces hepatic global and individual gene hypomethylation: Implications for arsenic hepatocarcinogenesis. Carcinogenesis 2004;25(9):1779-86.

20. Rizki M, Kossatz E, Velázquez A, Creus A, Farina M, Fortaner S, et al. Metabolism of arsenic in Drosophila melanogaster and the genotoxicity of dimethylarsinic acid in the Drosophila wing spot test. Environ Mol Mutagen 2006;47(3):162-8

21. Rossman TG, Stone D, Molina M, Troll W. Absence of arsenite mutagenicity in E coli and Chinese hamster cells. Environ Mutagen 1980;2(3):371-9.

22. Fischer JM, Robbins SB, Al-Zoughool M, Kannamkumarath SS, Stringer SL, Larson JS, et al. Co-mutagenic activity of arsenic and benzo [a] pyrene in mouse skin. Mutat Res 2005;588(1):35-46.

23. Singh KP, DuMond JW Jr. Genetic and epigenetic changes induced by chronic low dose exposure to arsenic of mouse testicular Leydig cells. Int J Oncol 2007;30(1):253-60. 